\title{
Enhanced biomass productivity of microalgae Nannochloropsis sp. in an airlift photobioreactor using low-frequency flashing light with blue LED
}

\author{
Novita Yustinadiar ${ }^{1 *} \mathbb{0}$, Robert Manurung ${ }^{2}$ and Gede Suantika ${ }^{3}$
}

\begin{abstract}
Microalgae Nannochloropsis sp. is a widely recognized renewable biodiesel feedstock. The ability of this microalgae to absorb $\mathrm{CO}_{2}$ constitutes an added value toward reducing global warming. However, the process of optimizing its growth still involves many challenges. Photoinhibition, which takes places during microalgae cultivation when using continuous lighting, constitutes an unresolved problem. Therefore, the optimum light/dark cycle method is considered necessary. The experiments were conducted using a designed, tubular airlift photobioreactor and blue, energy-saving, light-emitting diode (LED) lights for the purpose of internal illumination. We observed that a 45:15 min (light:dark) cycle increased the production of Nannochloropsis sp. biomass significantly, with a cell density, wet weight, and lipid content of $17 \times 10^{6} \mathrm{cell} / \mathrm{ml}, 7.11 \mathrm{~g}$, and $10.1 \%$ dry weight, respectively. By using the blue LED lights, our designed, airlift photobioreactor increased cell growth by $70 \%$ compared to the growth of Nannochloropsis sp. in nature and produced 61 times higher lipid content compared to Nannochloropsis sp. that is exposed to natural light.
\end{abstract}

Keywords: Nannochloropsis sp., Blue LED, Airlift photobioreactor, Low frequency

\section{Introduction}

In recent years, rates of world consumption of fuel and population growth show a constant increase. Based on BP (British Petroleum) data included in the 68th edition of World Energy Statistics 2019, total primary energy consumption (oil, natural gas, coal, nuclear energy, hydroelectric, and renewable energy) in 2018 was 13,864.9 million tons of oil equivalent. Total oil consumption was 4662.1 million tons, while renewable energy consumption was still low, at 561.3 million tons. Therefore, it is necessary to expand the use of renewable energy sources in order to address the limitations of fossil fuels.

Biodiesel is a renewable fuel that can substitute petroleum diesel fuel. Biodiesel is composed of various kinds

\footnotetext{
*Correspondence: novita.yustinadiar@ugm.ac.id

1 Plant Structure and Development Laboratory, Faculty of Biology, Gadjah

Mada University, Yogyakarta, Indonesia

Full list of author information is available at the end of the article
}

of fatty acid esters. Widely recognized sources of commercial biodiesel include soybean, canola oil, animal fat, palm oil, corn oil, used cooking oil, and castor oil (Chisti 2007; Kulkarni and Dalai 2006). Biodiesel raw materials that are derived from those plants are found in low quantities and present shortcomings in their production, which has an impact on the budget that is dedicated to food crops. Hence, we need a new source of biodiesel raw materials, which will combine a higher productivity with a more efficient use of land.

A previous study that used microalgae as an alternative source of biodiesel feedstock showed that they have a relatively fast harvest time and do not interfere with food crops (Wagner 2007). Marine microalgae constitute a useful form of biomass, not only as raw materials of bio-based products (biodiesel, animal feed, nutritional supplements), but also as a means to overcome environmental problems such as global warming, since 
they absorb $\mathrm{CO}_{2}$. According to Chisti (2008), one of the microalgal species that is more suitable for research and development as raw materials for various bio-based products in tropical country, specifically in Indonesia, is Nannochloropsis sp. This species shows the best combination of biomass productivity $(\sim 0.2 \mathrm{~g} / \mathrm{L}$ day $)$ and lipid content ( $30 \mathrm{wt} \%)$ (Allen et al. 2018; Rodolfi et al. 2009).

The previous study reported that the use of blue LED resulted in the optimum growth of Nannochloropsis sp. LED lights are used in order to improve energy efficiency and reduce operating costs (Das et al. 2011; Sudibyo et al. 2017; Taisir et al. 2016). On the other hand, the airlift column photobioreactor, which is widely accepted for industrial use, mixes efficiently circular fluid and airflow. It is characterized by a relatively lower cost in terms of manufacturing and is easy to operate and sterilize (Taisir et al. 2016). In addition to the above, it is also characterized by proper cell mixing, mass transfer, and low cell stress (Huang et al. 2017).

An industrial-scale technology that focuses on the production and conservation of microalgae biomass that can be used as biofuels and bioproducts has not been developed yet. Therefore, microalgal biomass is not ready for commercial use (Allen et al. 2018). Finding the suitable types of large-scale photobioreactors, photoinhibition under continuous light, and determining the appropriate energy-saving light sources constitute unsolved problems. This study optimized the production of microalgal culture determining the most suitable photobioreactor and light source. We intended to compare the effect of low-frequency flashing light using blue LED on an airlift photobioreactor system in order to enhance the growth and lipid levels of Nannochloropsis sp. We evaluated the energy efficiency of the use of the airlift photobioreactor in relation to the resulting lipid product.

\section{Materials and methods}

\section{Microorganisms used and the media composition}

The species of microalgae used in this study is the Nannochloropsis sp. Other materials that were used are aquades, aquatic deionization, alcohol, spiritus, Walne medium (Table 1) and modified Walne's medium II (Table 2), sea salt, sodium hypochlorite $(\mathrm{NaOCl})$, sodium thiosulfate $\left(\mathrm{Na}_{2} \mathrm{~S}_{2} \mathrm{O}_{3}\right)$, Nessler reagent, Seignette salt solution $\left(\mathrm{KNaC}_{4} \mathrm{H}_{4} \mathrm{O}_{6} \cdot 4 \mathrm{H}_{2} \mathrm{O}\right), \mathrm{NaCl}$ solution, sulfuric acid solution $\left(\mathrm{H}_{2} \mathrm{SO}_{4}\right)$, brucine sulfanilate $\left(\mathrm{C}_{29} \mathrm{H}_{33} \mathrm{~N}_{3} \mathrm{O}_{7} \mathrm{~S}\right)$ solution, naphthyl acid $\left(\mathrm{H}_{2} \mathrm{SO}_{4}\right)$ solution, sulfanilic acid solution $\left(\mathrm{NH}_{2} \mathrm{C}_{6} \mathrm{H}_{4} \mathrm{SO}_{3} \mathrm{H}\right)$, naphthyl $\left(\mathrm{C}_{12} \mathrm{H}_{14} \mathrm{~N}_{2} \mathrm{H}_{2} \mathrm{O}_{2}\right)$ chloride solution, and chloride (Oo et al. 2017).
Table 1 Walne medium composition (Anderson 2005; Oo et al. 2017)

\begin{tabular}{|c|c|c|c|}
\hline Stock & No. & Substances & Volume \\
\hline \multirow[t]{8}{*}{ I } & \multicolumn{3}{|c|}{ A Solution (per liter distilled water) } \\
\hline & 1. & $\mathrm{FeCl}_{3} \cdot 6 \mathrm{H}_{2} \mathrm{O}$ & $1.3 \mathrm{~g}$ \\
\hline & 2. & $\mathrm{MnCl}_{2} \cdot 4 \mathrm{H}_{2} \mathrm{O}$ & $0.36 \mathrm{~g}$ \\
\hline & 3. & $\mathrm{H}_{3} \mathrm{BO}_{3}$ & $33.6 \mathrm{~g}$ \\
\hline & 4. & EDTA & $45 \mathrm{~g}$ \\
\hline & 5. & $\mathrm{NaH}_{2} \mathrm{PO}_{4} \cdot 2 \mathrm{H}_{2} \mathrm{O}$ & $20 \mathrm{~g}$ \\
\hline & 6. & $\mathrm{NaNO}_{3}$ & $100 \mathrm{~g}$ \\
\hline & 7. & B Solution & $1 \mathrm{~mL}$ \\
\hline \multirow[t]{6}{*}{$\|$} & \multicolumn{3}{|c|}{ B Solution (per $100 \mathrm{~mL}$ distilled water) } \\
\hline & 1. & $\mathrm{ZnCl}_{2}$ & $2.1 \mathrm{~g}$ \\
\hline & 2. & $\mathrm{CoCl}_{2} \cdot 6 \mathrm{H} 2 \mathrm{O}$ & $2 \mathrm{~g}$ \\
\hline & 3. & $\left(\mathrm{NH}_{4}\right)_{6} \mathrm{Mo}_{7} \mathrm{O}_{24} \cdot 4 \mathrm{H}_{2} \mathrm{O}$ & $0.9 \mathrm{~g}$ \\
\hline & 4. & $\mathrm{CuSO}_{4} \cdot 5 \mathrm{H}_{2} \mathrm{O}$ & $2 \mathrm{~g}$ \\
\hline & 5. & Concentrated $\mathrm{HCl}$ & $10 \mathrm{~mL}$ \\
\hline \multirow[t]{3}{*}{ III } & \multicolumn{3}{|c|}{ C Solution (per 200 mL distilled water) } \\
\hline & 1. & Vitamin B1 & $0.2 \mathrm{~g}$ \\
\hline & 2. & Vitamin B12 & $10 \mathrm{mg}$ \\
\hline \multicolumn{4}{|c|}{ Medium } \\
\hline 1. & A Solution & & $1 \mathrm{~mL} / \mathrm{L}$ \\
\hline 2. & B Solution & & $0.1 \mathrm{~mL} / \mathrm{L}$ \\
\hline 3. & Sterile seawater & & $1 \mathrm{~L}$ \\
\hline
\end{tabular}

Table 2 Composition of modified Walne's medium II (Le Chevanton et al. 2016)

\begin{tabular}{llc}
\hline No. & Material & $\begin{array}{l}\text { Concentration } \\
(\mathbf{m g} / \mathbf{L})\end{array}$ \\
\hline 1. & Ammonium sulfate $\left(\left(\mathrm{NH}_{4}\right)_{2} \mathrm{SO}_{4}\right)$ & 148.37 \\
2. & Urea $\left(\mathrm{CH}_{4} \mathrm{~N}_{2} \mathrm{O}\right)$ & 7.5 \\
3. & Iron (III) chloride $\left(\mathrm{FeCl}_{3}\right)$ & 2 \\
4. & Ethylenediaminetetraacetic acid (EDTA) & 5 \\
5. & Monopotassium phosphate $\left(\mathrm{KH}_{2} \mathrm{PO}_{4}\right)$ & 29 \\
6. & Iron (II) sulfate $\left(\mathrm{FeSO}_{4} \cdot 7 \mathrm{H}_{2} \mathrm{O}\right)$ & 5.136 \\
\hline
\end{tabular}

\section{Photobioreactor design}

The photobioreactor that was used in our study is a tubeshaped, airlift photobioreactor with a length of $50 \mathrm{~cm}$ and a diameter of $30 \mathrm{~cm}$, as shown in Fig. 1. In the center of the inner circle of the photobioreactor, we placed a small tube, $55 \mathrm{~cm}$ long and $5 \mathrm{~cm}$ in diameter. The top and bottom of the tube are cone-shaped. The total volume of the photobioreactor, which was made from acrylic material with a thickness of $0.6 \mathrm{~mm}$, is $50 \mathrm{~L}$. Between the outer and inner tube, there are six series of blue LED lights that are arranged around the inner tube. The LED lights used are ribbon-shaped, blue LED strips. The specifications of the LED lights include a light intensity for each 


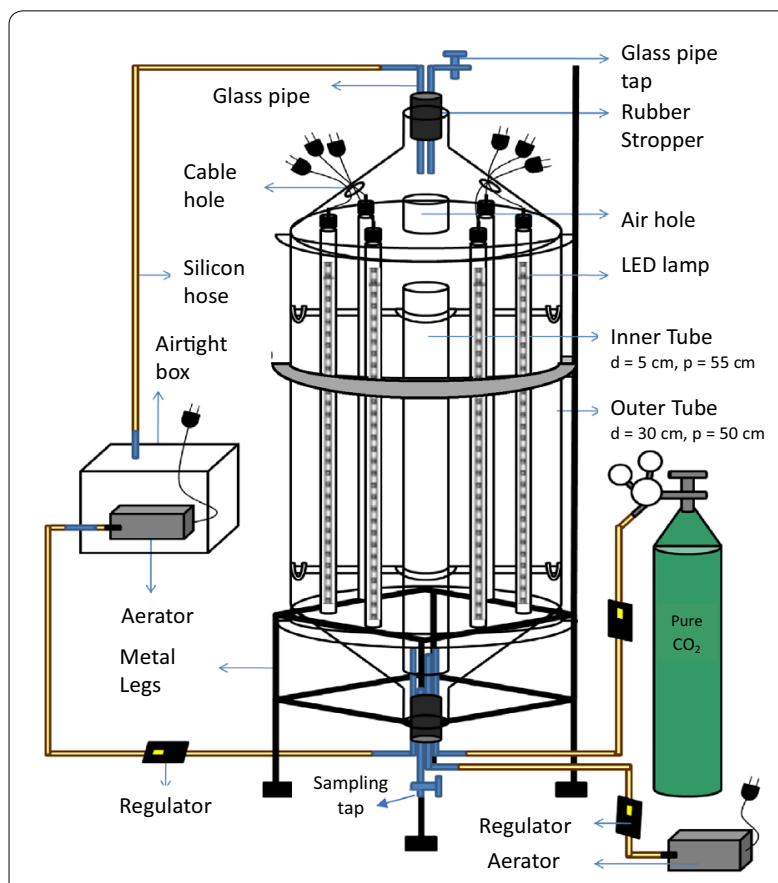

Fig. 1 Airlift photobioreactor design with six series of blue LED lamps and pure $\mathrm{CO}_{2}$ source

LED lamp of $0.824 \mathrm{~W} / \mathrm{m}^{2}$, wavelength of blue lights of $463-475 \mathrm{~nm} / \mathrm{K}$, total electricity consumption (6 series of lights $=4.944 \mathrm{~W} / \mathrm{m}^{2}$ ) of $86.4 \mathrm{~W}, 50,000 \mathrm{~h}$ lifetime, and 12 $\mathrm{V}$ voltage. The LED strip lights are placed using glue on the small wooden beams of each of the four sides and are protected with waterproof glass tubes so that they form a series of waterproof tube lights $50 \mathrm{~cm}$ long and $1.85 \mathrm{~cm}$ in diameter.

For the creation of the air aeration system, an airlift flow system was combined with circulation (recycling) of air in order for the air to be re-flowed into the photobioreactor. The air circulation process was carried out using an aerator that was stored in an airtight box and connected to the outlet pipe faucet. In that way, the aerator could only absorb the air coming out of the photobioreactor. This air recycling system was created in order to improve the efficiency of $\mathrm{CO}_{2}$ usage in photobioreactors. The airlift photobioreactor used in this study was closed in order to minimize the number of contaminants from the surrounding environment.

We evaluated the light intensity produced by six installed blue LED lamps. However, the light intensity did not reach the value of $12.2074 \mathrm{~W} / \mathrm{m}^{2}$, which is the optimum light intensity for the growth of Nannochloropsis sp (Aziz and Dianursanti 2018). Therefore, four additional lamps were installed outside the tube, vertically, in order to increase the total light intensity to $12.2074 \mathrm{~W} / \mathrm{m}^{2}$.

\section{Inoculum preparation}

Small glass equipment was sterilized using an autoclave at a temperature of $121{ }^{\circ} \mathrm{C}$ and a pressure of $1.5 \mathrm{~atm}$, for $15 \mathrm{~min}$. Meanwhile, large equipment that could not enter the autoclave was sterilized using the chlorination technique. The ingredients used included pro-analyst and commercial materials such as ZA (nitrogen) fertilizer and urea.

Walne medium (Table 1) was used as the growth medium of Nannochloropsis sp. while preparing the inoculum, while Modification II medium (Table 2) was used for the mass culture. The artificial seawater that was used was made by dissolving sea salt with fresh water. After the dissolution of the yellow salt iron $\left(\mathrm{Fe}^{3+}\right)$, the deposits must be removed before they can be used for the microalgae culture because they will affect the nutritional quality of the medium (Oo et al. 2017).

We sterilized $1 \mathrm{~L}$ seawater medium in the bottles using an autoclave. Moreover, larger-scale cultures can be sterilized using chlorination techniques. The chlorination technique was carried out by adding $10 \mathrm{ppm}$ sodium hypochlorite $(\mathrm{NaOCl})$ to the medium and leaving it for $24 \mathrm{~h}$ in strong aeration. Further, $10 \mathrm{ppm}$ of sodium thiosulfate $\left(\mathrm{Na}_{2} \mathrm{~S}_{2} \mathrm{O}_{3}\right)$ was added to the medium, which serves to neutralize the chlorine contained in the medium. The medium was ready after $6 \mathrm{~h}$ and was characterized by a significant loss of chlorine odor. The preparation of inoculum Nannochloropsis sp. was performed under cultivation conditions of salinity of $35+1 \mathrm{ppt}, \mathrm{pH}$ of 7.8, temperature of $28+1{ }^{\circ} \mathrm{C}$, light intensity of $7.6296 \mathrm{~W} / \mathrm{m}^{2}$, photoperiod of $24 / 0 \mathrm{~h}$, and aeration rate of $100 \mathrm{~mL} / \mathrm{L} /$ min. On day 0 , the cell density in the medium was set at $1 \times 10^{6} \mathrm{cells} / \mathrm{mL}$ in all treatments. The maintenance of inoculum was carried out by subculture once in every 5-day culture period.

\section{Nannochloropsis sp. cultivation}

Our study began with a preliminary study on variations of the quantity of pure $\mathrm{CO}_{2}$ that has to be added. Concentrations of $0,2,4,6$, and $8 \%$ of total aeration fluid of $100 \mathrm{~mL} / \mathrm{L} / \mathrm{min}$ or equivalent to $0.59,36.07,71.55$, 107.03 and $142.51 \mathrm{ppm}$ of $\mathrm{CO}_{2}$ per minute on a 1-L scale were used (Fig. 2). Each variation of the treatment was repeated three times. The amount of Nannochloropsis sp., living and dead, and contaminants, various water quality parameters (ammonium, nitrate, nitrite, and orthophosphate), temperature, and acidity level $(\mathrm{pH})$ were measured during the culture period. Our aim was to obtain the best conditions regarding aeration and fluid $\mathrm{CO}_{2}$ concentration for the growth and the maximum lipid levels of Nannochloropsis sp. 


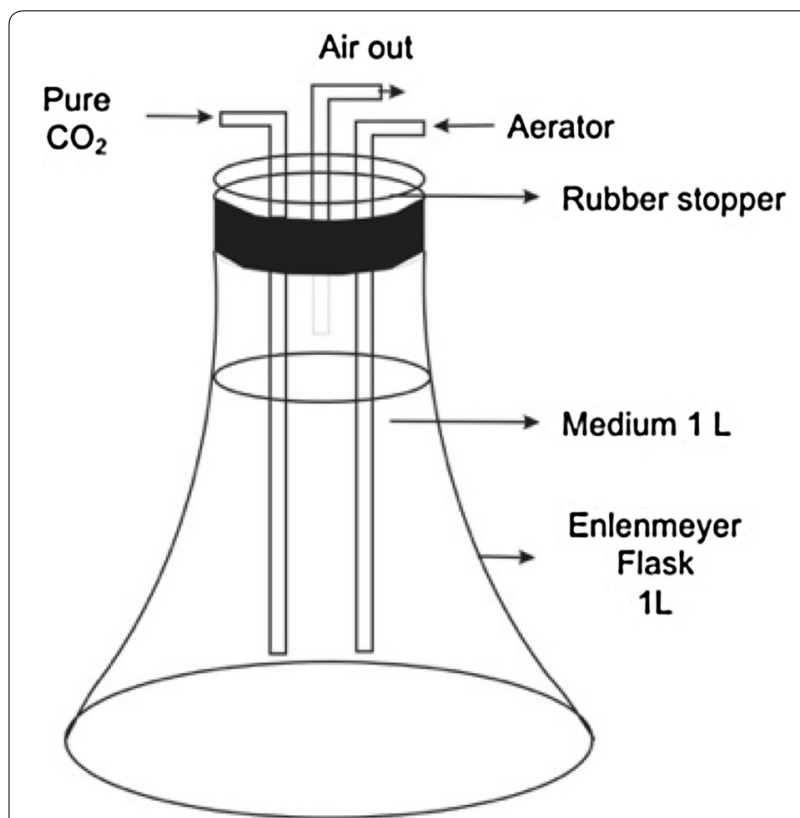

Fig. 2 Treatment of variation in aeration fluid $\mathrm{CO}_{2}$ concentration $0 ; 2$; $4 ; 6$; and $8 \%$ and aeration diagrams

Table 3 Treatment in 35-L airlift photobioreactors

\begin{tabular}{lll}
\hline Treatment & $\begin{array}{l}\text { Flashing light in 1-h period } \\
\text { (light:dark) }\end{array}$ & Symbol \\
\hline Control & - & $\begin{array}{l}\text { Control (natural } \\
\text { photoperi- } \\
\text { Odism) }\end{array}$ \\
$\mathbf{1}$ & $0.75: 0.25 \mathrm{~h}$ & $\mathrm{P} 1(0.75: 0.25 \mathrm{~h})$ \\
$\mathbf{2}$ & $0.5: 0.5 \mathrm{~h}$ & $\mathrm{P} 2(0.5: 0.5 \mathrm{~h})$ \\
$\mathbf{3}$ & $0.25: 0.75 \mathrm{~h}$ & $\mathrm{P} 3(0.25: 0.75 \mathrm{~h})$ \\
\hline
\end{tabular}

The next step in the procedure was to conduct cultivation in a $35-\mathrm{L}$ airlift photobioreactor using variations in the conditions of photoperiodism and low-frequency flashing light, as shown in Table 3. For the control treatment, the lights were turned on without flashing light with a photoperiodism ratio of $12: 12 \mathrm{~h}$ following conditions in natural habitat for 12 days.

In the first treatment, we used low-frequency flashing light in an hourly period, with a ratio of 0.75:0.25 h (light:dark). In the second treatment we used a flashing light ratio of 0.5:0.5 h, while treatment 3 had a flashing light ratio of $0.25: 0.75 \mathrm{~h}$. The three flashing light treatments were carried out within a time span of $24 \mathrm{~h}$, for a period of 12 days.

The calculations of the cell population of Nannochloropsis sp. and contaminants were carried out on a daily basis using a counting chamber (Guillard and Sieracki 2005). The way to distinguish the living from the dead cells is through staining, using the Evans Blue dye solution. Dead microalgae cells absorb the color so they are characterized by blue color, while those that are still alive will keep their green color. Using the results of these growth measurements, specific growth rates can be calculated using the formula (Krzemińska et al. 2014) as follows:

$$
\mu=\frac{\left(\ln N_{t}-\ln N_{0}\right)}{\Delta t},
$$

where $\mu$ is the specific growth rate, $\Delta t$ is the cultivation period $\left(t_{1}-t_{0}\right)$, and $N_{0}$ and $N_{t}$ are the biomass at time $0\left(t_{0}\right)$ and time $1\left(t_{1}\right)$, respectively.

The water quality parameters that were measured include temperature, $\mathrm{pH}$, ammonium, nitrate, nitrite, and orthophosphate levels. Measurements of temperature and $\mathrm{pH}$ were carried out at 24-h intervals, whereas for ammonium, nitrate, nitrite, orthophosphate, dissolved $\mathrm{CO}_{2}$, and dissolved $\mathrm{O}_{2}$ levels, the measurements were carried out at 48-h intervals.

Harvesting of Nannochloropsis sp. biomass was carried out using the centrifugation technique of $12,000 \mathrm{~g}$ at $4^{\circ} \mathrm{C}$ for $10 \mathrm{~min}$ in order to obtain wet biomass in the form of a paste. After weighing, the wet biomass was dried in an oven at $60^{\circ} \mathrm{C}$ for $24 \mathrm{~h}$ until it was dry.

Further, the dried Nannochloropsis sp. biomass was extracted using the Bligh and Dyer method (Bligh and Dyer 1959; Lee et al. 2010). The lipid fraction of the biomass was extracted by maceration, using chloroform and methanol as solvents. The filtering process, which was carried out with filter paper in order to remove dissolved particles, was followed by the separation of the solvent layer and the lipid extract layer, using evaporation. The lipid extracts that were obtained were measured to determine the lipid levels per dry weight of biomass.

\section{Data analysis}

All data obtained were statistically calculated using a variance analysis test one-way analysis of variance (oneway ANOVA) aimed at determining the significance of the differences between the several treatments. Further, the significance of the average difference was evaluated using the Duncan test (Marrez et al. 2017). In addition, a Pearson correlation test was performed in order to determine the correlation between biotic (the number of $\mathrm{Nan}$ nochloropsis sp. cells) and culture abiotic factors.

\section{Results and discussion}

Cultivation of Nannochloropsis sp. and variations in $\mathrm{CO}_{2}$ concentration

During the experimental stage, the variations in $\mathrm{CO}_{2}$ concentrations showed that the highest growth was obtained from the control treatments that were 
characterized by the addition of $0 \% \mathrm{CO}_{2}$ (Fig. 3a). At the end of the culture period, aeration of $\mathrm{CO}_{2}$ concentration of $0 \%$ gave the cell density its highest value $\left(10.73 \times 10^{6}\right.$ cells $\left./ \mathrm{mL}\right)$. Aeration of $\mathrm{CO}_{2}$ concentration of $2 \%$, which is considered to be the optimum $\mathrm{CO}_{2}$ concentration for the culture of Nannochloropsis sp. (Chiu et al. 2009), was shown to produce a cell density that was less than the case of $0 \%$ and specifically only $6.3 \mathrm{x}$ $10^{6}$ cells $/ \mathrm{mL}$. The $\mathrm{CO}_{2}$ concentration of $0 \%(0.59 \mathrm{ppm})$ means the culture of Nannochloropsis sp. is performed without any addition of $\mathrm{CO}_{2}\left(0 \%\right.$ treatment), then $\mathrm{CO}_{2}$ is absorbed from the air in the surrounding environment at a concentration of $0.59 \mathrm{ppm}$. Adding aeration with $0 \%$ concentration in $\mathrm{CO}_{2}$ results in an increase in cell growth of approximately $70.3 \%$ compared to the treatment that involves adding aeration with a $2 \%$ concentration in $\mathrm{CO}_{2}$. The treatment of aeration with fluid $\mathrm{CO}_{2}$ concentrations above $2 \%(4 ; 6$; and $8 \%)$, as shown in (Fig. 3a), led to a decrease in the cells, from the beginning to the end of the culture period. Addition of aeration with $8 \% \mathrm{CO}_{2}$ fluid resulted in the lowest cell density $\left(0.43 \times 10^{6}\right.$ cells $\left./ \mathrm{mL}\right)$. The phenomenon of decreased cells during the treatment is considered to be the result of the large number of dead cells (Fig. 3b). The highest number of dead cells was found in the treatment of $8 \% \mathrm{CO}_{2}$ addition $\left(0.33 \times 10^{6}\right.$ cells $\left./ \mathrm{mL}\right)$, but the lowest number of contaminants in this treatment was calculated at $0.03 \times 10^{6}$ cells $/ \mathrm{mL}$ (Fig. 3c). It is suspected that the death of the cells is caused not only by contaminants, but also by environmental conditions that do not support the growth of microalgae due to the presence of $\mathrm{CO}_{2}$ inhibition.

The results of the $t$ test analysis for cultures with treatments with $\mathrm{CO}_{2}$ concentrations of $0 \%$ and $2 \%$ showed that the two treatments were significantly different. On the other hand, the results of the t-test analysis for cultures with treatments related to $\mathrm{CO}_{2}$ concentrations of 4,6 , and $8 \%$ showed that the three treatments were not significantly different. The results of statistical tests using ANOVA indicate that there is a significant difference
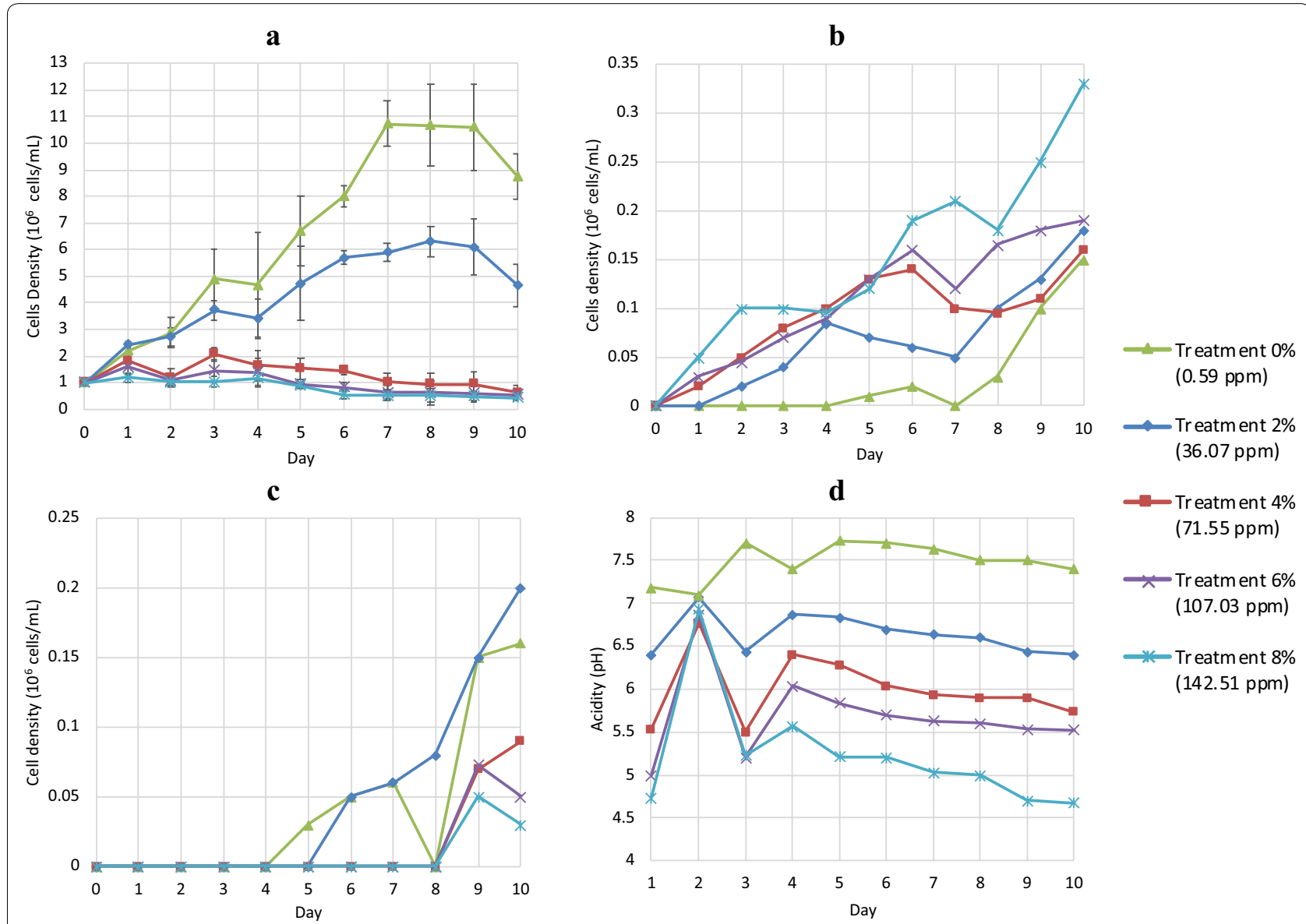

Fig. 3 Five treatments of $\mathrm{CO}_{2}$ concentration during aeration fluid consisting of $0.59,36.07,71.55,107.03$ and 142.51 ppm for (a) Nannochloropsis sp. growth curve with one sigma standard deviation, (b) Nannochloropsis sp. cell death rate curve, (c) contaminant growth, and (d) acidity level (pH) of Nannochloropsis sp 
$(p<0.05)$ in the average value of growth when the addition of $\mathrm{CO}_{2}$ ranges between $0 \%$ and $8 \%$.

It is suspected that with the addition of aeration fluid with $\mathrm{CO}_{2}$ concentrations of above $2 \%$, the inhibitory activity of excess $\mathrm{CO}_{2}$ against the photosynthetic activity takes place. According to Silva and Pirt (1984), the $\mathrm{CO}_{2}$ inhibition activity is related to the equilibrium between $\mathrm{CO}_{2}$ at the gas phase and $\mathrm{H}_{2} \mathrm{O}$ at the liquid phase. The higher the concentrations of $\mathrm{CO}_{2}$ in the water, the higher the concentrations of bicarbonate. The inhibition process occurs due to changes in the osmotic pressure as a result of the increase of concentrations of $\mathrm{NaHCO}_{3}$ salt that forms in a way that affects the activity of the enzyme Rubisco (ribulose biphosphate carboxylase), which in turn plays a role in the photosynthesis process.

According to Chiu et al. (2009), the addition of $\mathrm{CO}_{2}$ to aeration fluid by $2 \%$ provides the optimum value for the growth rate of Nannochloropsis sp., while when the concentration of $\mathrm{CO}_{2}$ in the aeration fluid is above 2, 5, 10, and $15 \%$, inhibitory reactions to growth appear. Based on $\mathrm{Xu}$ et al. (2004) research, the optimum aeration rate for the growth of Nannochloropsis $s p$. is $100 \mathrm{ml} / \mathrm{L} / \mathrm{min}$ with the addition of $0.5 \%$ of pure $\mathrm{CO}_{2}$, which results in the optimum growth. Based on the results obtained in this study, it is shown that the addition of $\mathrm{CO}_{2}$ concentrations of $0 \%(0.59 \mathrm{ppm})$ has an optimum impact on the growth rate of Nannochloropsis sp., while the addition of $\mathrm{CO}_{2}$ concentrations of $2,4,6$, and $8 \%$ in aeration fluid results in inhibitory reactions to the growth of microalgae, as it is proven by the increasing number of dead cells (Fig. 3b). The addition of $\mathrm{CO}_{2}$ concentrations in the aeration fluid can have an impact on the changes in the degree of acidity $(\mathrm{pH})$ of the medium.

The acidity level of Nannochloropsis sp., when compared among the several treatments, exhibits significant differences. The higher the concentration of $\mathrm{CO}_{2}$ added to the aeration fluid, the lower (acidic) the $\mathrm{pH}$ of the medium becomes (Fig. 3d). The $\mathrm{pH}$ of the medium of each treatment tends to increase slightly at the beginning of the culture period. At the end of the culture period, $\mathrm{pH}$ decreases due to the increase of organic matter from the dead cells. At the beginning of the culture period, the highest degree of acidity ( $\mathrm{pH}$ 7.1) was obtained from the treatment that involved addition of a concentration of $0 \%$ $\mathrm{CO}_{2}$ while with the addition of $2 \%$ of $\mathrm{CO}_{2}$ the value of the $\mathrm{pH}$ was 6.4.

Since the beginning of the culture period, the treatment of adding $\mathrm{CO}_{2}$ concentrations above $2 \%$ produced a low $\mathrm{pH}$ value (below 5.5). The $\mathrm{pH}$ value increased slightly until the third day and then decreased until the end of the culture period, ranging from $7.4(0 \%)$ to $4.6(8 \%)$. According to Rocha et al. (2003), the $\mathrm{pH}$ range for the optimum growth of Nannochloropsis sp., is between 7 and 8.5. PH conditions that are too acidic, such as those produced in the treatment of increasing $\mathrm{CO}_{2}$ concentrations of 4,6 , and $8 \%$, are considered to cause inactivation of the work of enzymes that participate in the process of metabolism of microalgae. These metabolic disorders inhibit growth and can lead to cell death.

During the culture period, the concentrations of ammonium, nitrate, and nitrite in the Nannochloropsis sp. culture tended to increase, whereas orthophosphate concentrations in all treatments with variations in $\mathrm{CO}_{2}$ concentrations in aeration fluid tended to decrease (Fig. 4). Ammonium, nitrate, and nitrite levels that were determined by the composition of the Walne medium were higher than the ones determined by the composition of the modified Walne II medium. This can be extracted by the measurement results of ammonium, nitrate, and nitrite in Fig. 4(a-d).

According to our observation (Additional file 1: Table S1), the ammonium, nitrate, and nitrite concentration parameters in the treatment with $\mathrm{CO}_{2}$ additions of $0 \%$ and $2 \%$ show a positive correlation with the growth of Nannochloropsis sp. On the other hand, the ammonium, nitrate, and nitrite concentration parameters in the treatments with $\mathrm{CO}_{2}$ additions of 4,6 , and $8 \%$ show a negative correlation with the growth of Nannochloropsis sp. In the second case, this difference is considered to be caused by cell death occurring at the beginning of the treatment process. Although there is sufficient nutrition in the culture, high concentrations of dissolved $\mathrm{CO}_{2}$ (above $2 \%$ ) produce cell death, which inhibits the growth of the culture of Nannochloropsis sp. The orthophosphate concentration shows a negative correlation only in the treatments that involved the addition of $\mathrm{CO}_{2}$ by $0 \%$ and $2 \%$. The degree of acidity $(\mathrm{pH})$ shows a negative correlation in almost all treatments except for the treatment of $0 \%$ addition of $\mathrm{CO}_{2}$.

Ammonium is a chemical compound represented by the chemical formula $\mathrm{NH}_{4}$. It is formed by the protonation of ammonia $\left(\mathrm{NH}_{3}\right)$. The fluctuating concentration of ammonium is considered to be caused by several factors that affect the culture of Nannochloropsis sp. The increased ammonium concentration is a result of the remnants of the cell death of Nannochloropsis sp. The dead biomass is an organic material that is decomposed by the bacteria in the medium and secretes ammonia compounds. Ammonia formed in water protonates to ammonium. Nitrate $\left(\mathrm{NO}_{3}\right)$ is the main form of nitrogen in natural waters and is the primary nutrient for microalgae growth (Chen and Lee 2012).

Nitrates are stable and very soluble in water. Nitrate compounds are produced by the complete oxidation of nitrogen compounds found in water. The oxidation of ammonia to $\mathrm{NO}_{2}$ is carried out by the bacterium 


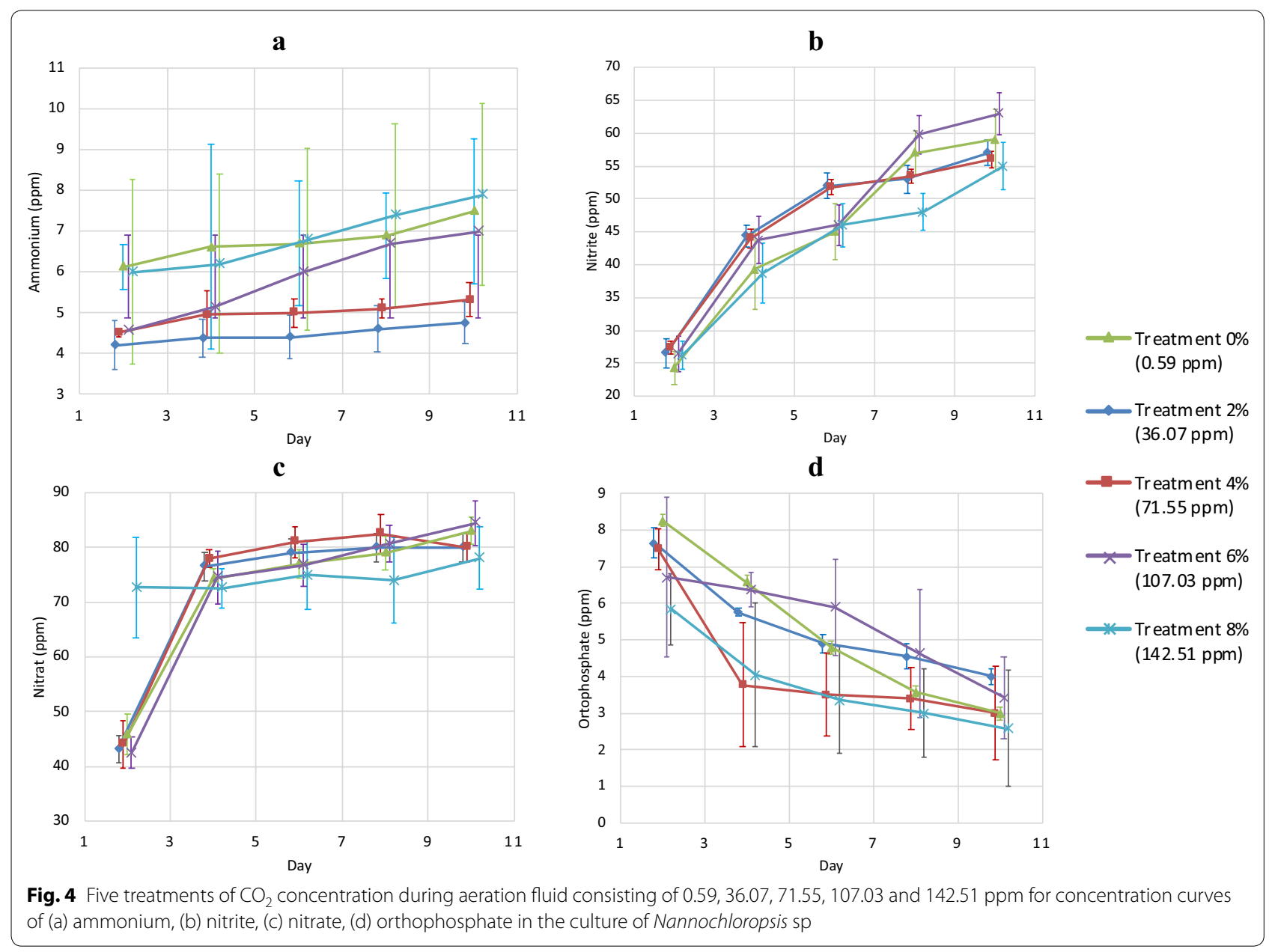

Nitrosomonas, while the oxidation of $\mathrm{NO}_{2}$ to $\mathrm{NO}_{3}$ is carried out by Nitrobacter. The $\mathrm{NO}_{3}$ that is absorbed by microalgae is converted into protein (Chen and Lee 2012). In addition to the above, low consumption of ammonium and nitrate absorption indicate a present, relatively low growth.

Nitrite compounds $\left(\mathrm{NO}_{2}\right)$ found in water are the result of either the reduction of nitrate compounds $\left(\mathrm{NO}_{3}\right)$ or the oxidation of ammonia $\left(\mathrm{NH}_{3}\right)$ by microorganisms. The increase in nitrite compounds (Fig. 4b) is considered to originate in the excretion of microalgae, especially when an explosion of the microalgae population occurs. Moreover, increased levels of nitrites are closely related to the entry of biodegradable organic matter (whether containing nitrogen or not), such as the remnants of dead microalgae cells. Nitrites are usually found in minimal amounts, smaller than nitrates, because they are unstable under the presence of $\mathrm{O}_{2}$ (Bothe et al. 2007).

Orthophosphate $\left(\mathrm{O}-\mathrm{PO}_{4}\right)$, an ionization (Table 4) product of orthophosphoric acid, is the purest form of phosphorus and is found in many waters. Orthophosphate can be utilized directly by microalgae as a macronutrient (Solovchenko et al. 2016). When the levels of PO4 in the ocean increase, an explosion of phytoplankton populations occurs. A significant decrease in orthophosphate concentration on the 4th day of the culture period (Fig. 4d) indicates the absorption of phosphate by microalgae culture in large numbers, when growth reaches an exponential phase. This result, supported by Solovchenko et al. (2016), demonstrates that microalgal P (phosphorus) uptake increases at low $\mathrm{CO}_{2}$ level.

Based on the calculation results, the flashing light treatment affects the growth of Nannochloropsis sp. P1 corresponds to a flashing light treatment (45:15 min, light:dark period of $1 \mathrm{~h}$ ) with a total irradiation period of $18 \mathrm{~h}$ of light for $24 \mathrm{~h}$ (Fig. 5). At the end of the culture period, the P1 $(0.75: 0.25 \mathrm{~h})$ flashing light treatment resulted in the highest cell density $\left(17 \times 10^{6}\right.$ cells $\left./ \mathrm{mL}\right)$ with a growth rate of $\mu=0.25 /$ day (Table 4 ). This result was followed by the P2 treatment $(0.5: 0.5 \mathrm{~h})$ with a cell density of $10 \mathrm{x}$ $10^{6}$ cells $/ \mathrm{mL}$ and a growth rate of $\mu=0.2 /$ day, followed by the control treatment (conditions similar to nature) with 
Table 4 Population growth of Nannochloropsis sp. on the flashing light treatment

\begin{tabular}{|c|c|c|c|c|c|c|c|c|}
\hline \multirow[t]{3}{*}{ Day } & \multicolumn{8}{|c|}{ Flashing light (light:dark) } \\
\hline & \multicolumn{2}{|c|}{$\begin{array}{l}\text { Control (natural } \\
\text { photoperiodism) }\end{array}$} & \multicolumn{2}{|c|}{ P1 (0.75:0.25 h) } & \multicolumn{2}{|l|}{$\mathrm{P} 2(0.5: 0.5 \mathrm{~h})$} & \multicolumn{2}{|l|}{ P3 (0.25:0.75 h) } \\
\hline & $\begin{array}{l}\text { Cell density } \\
\left(10^{6} \text { cells } / \mathrm{mL}\right)\end{array}$ & $\begin{array}{l}\text { Specific growth } \\
\text { rate }(\mu) \text { (per day) }\end{array}$ & $\begin{array}{l}\text { Cell density } \\
\left(10^{6} \text { cells } / \mathrm{mL}\right)\end{array}$ & $\begin{array}{l}\text { Specific growth } \\
\text { rate }(\mu) \text { (per day) }\end{array}$ & $\begin{array}{l}\text { Cell density } \\
\left(10^{6} \text { cells } / \mathrm{mL}\right)\end{array}$ & $\begin{array}{l}\text { Specific growth } \\
\text { rate }(\mu) \text { (per day) }\end{array}$ & $\begin{array}{l}\text { Cell density } \\
\left(10^{6} \text { cells } / \mathrm{mL}\right)\end{array}$ & $\begin{array}{l}\text { Specific growth } \\
\text { rate }(\mu) \text { (per } \\
\text { day) }\end{array}$ \\
\hline 0 & 1 & 0 & 1 & 0 & 1 & 0 & 1 & 0 \\
\hline 1 & $1.03 \pm 0.25$ & 0.03 & $1.75 \pm 0.07$ & 0.55 & $1.3 \pm 0.08$ & 0.26 & $1.46 \pm 0.08$ & 0.38 \\
\hline 2 & $1.46 \pm 0.21$ & 0.19 & $2 \pm 0.35$ & 0.34 & $1.45 \pm 0.21$ & 0.18 & $0.81 \pm 0.07$ & -0.1 \\
\hline 3 & $1.93 \pm 0.23$ & 0.21 & $2.35 \pm 0.22$ & 0.28 & $2 \pm 0.15$ & 0.23 & $0.81 \pm 0.07$ & -0.06 \\
\hline 4 & $2.46 \pm 0.21$ & 0.22 & $4.8 \pm 0.40$ & 0.39 & $2.3 \pm 0.30$ & 0.2 & $0.76 \pm 0.20$ & -0.06 \\
\hline 5 & $3.11 \pm 0.07$ & 0.22 & $6.1 \pm 0.51$ & 0.36 & $3.1 \pm 0.25$ & 0.22 & $0.75 \pm 0.02$ & -0.05 \\
\hline 6 & $3.6 \pm 0.13$ & 0.21 & $7.98 \pm 0.05$ & 0.34 & $4 \pm 0.09$ & 0.23 & $0.55 \pm 0.13$ & -0.09 \\
\hline 7 & $3.66 \pm 0.35$ & 0.18 & $12.34 \pm 0.02$ & 0.35 & $6.8 \pm 0.06$ & 0.27 & $0.55 \pm 0.10$ & -0.08 \\
\hline 8 & $4.08 \pm 1.63$ & 0.17 & $15.4 \pm 0.23$ & 0.34 & $7.5 \pm 0.16$ & 0.25 & $0.45 \pm 0.10$ & -0.09 \\
\hline 9 & $4.63 \pm 0.51$ & 0.17 & $16.5 \pm 0.02$ & 0.31 & $8 \pm 0.06$ & 0.23 & $0.5 \pm 0.13$ & -0.07 \\
\hline 10 & $4.61 \pm 0.42$ & 0.15 & $16.8 \pm 0.14$ & 0.28 & $9.5 \pm 0.10$ & 0.22 & $0.63 \pm 0.05$ & -0.04 \\
\hline 11 & $4.7 \pm 0.43$ & 0.14 & $17 \pm 0.28$ & 0.25 & $9.9 \pm 0.19$ & 0.2 & $0.55 \pm 0.10$ & -0.05 \\
\hline 12 & $4.51 \pm 0.25$ & 0.12 & $17 \pm 0.02$ & 0.23 & $10 \pm 0.05$ & 0.19 & $0.26 \pm 0.10$ & -0.11 \\
\hline
\end{tabular}

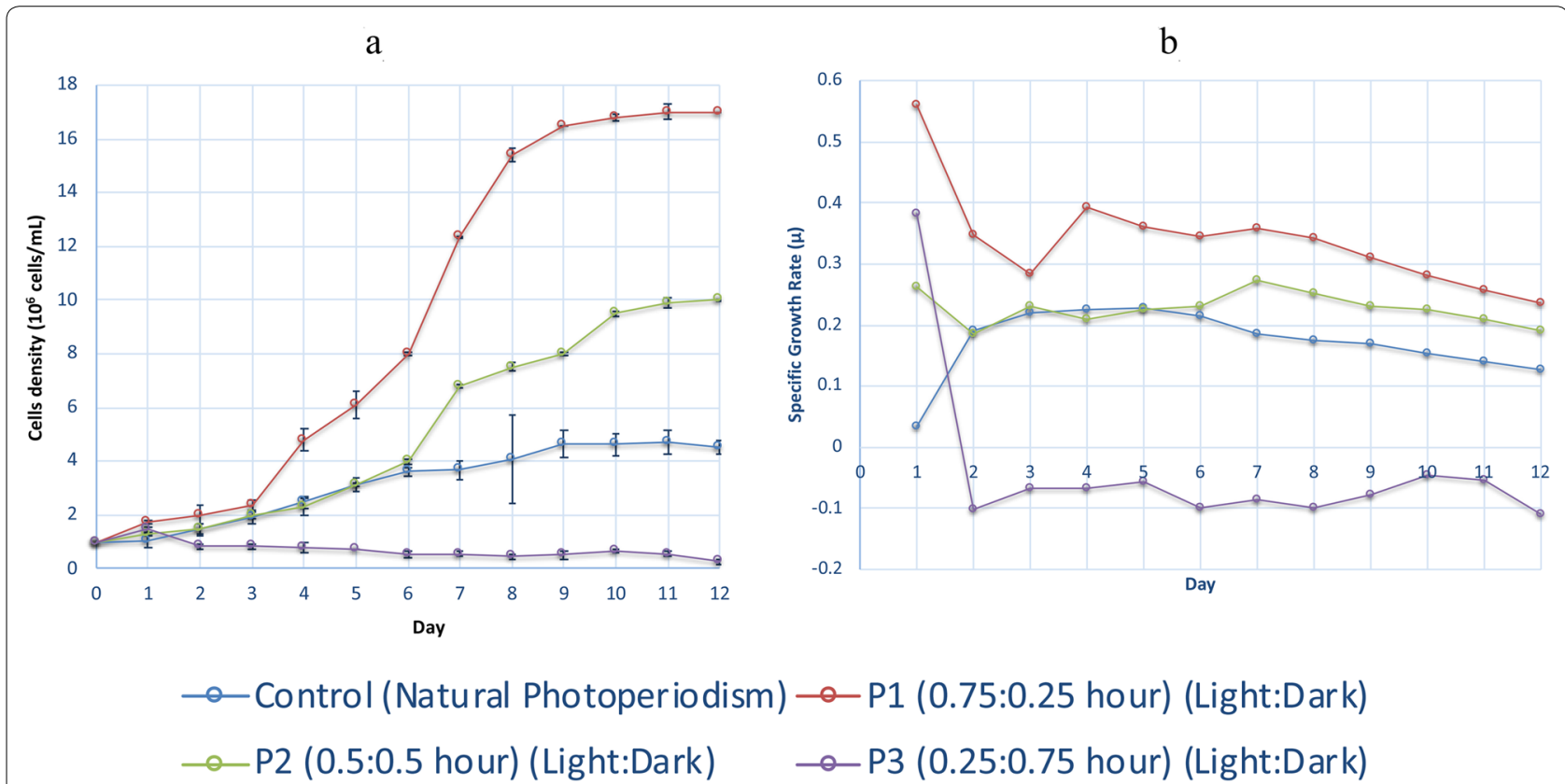

Fig. 5 (a) Growth curve with one sigma standard deviation and (b) specific growth rate for Nannochloropsis sp. on the four low-frequency flashing light treatments

a cell density of $4.7 \times 10^{6}$ cells $/ \mathrm{mL}$ and a growth rate of $\mu=0.14 /$ day. The highest growth rate was $\mu=0.55 /$ day observed at P1 treatment on day 1.

The control treatment in airlift photobioreactors that did not involve a flashing light (high irradiation follows conditions in nature) is considered to result in a higher density of Nannochloropsis sp. compared to natural conditions. The cell density of Nannochloropsis sp., which grows in nature, can reach $10^{7}$ cells $/ \mathrm{mL}$ (Chen and Lee 2012). The cell size of Nannochloropsis sp., which is cultured in an airlift photobioreactor with a blue LED light, is greater than the size of the cell that is cultured in an 
Erlenmeyer tube with a white (tube light) TL lamp. Based on these observations, we can consider that the use of airlift photobioreactors that use blue LED lights with a P1 treatment $(0.75: 0.25 \mathrm{~h})$ can increase the production of Nannochloropsis sp. by 70\% compared to the growth of Nannochloropsis sp. in nature. ANOVA (one way) statistical test results indicate that there is a significant difference $(\mathrm{p}<0.05)$ in the average growth value of Nannochloropsis sp., when it grows with a different flashing light treatment.

In almost all treatments, at the beginning of the culture period (from day 1 to day 3), the growth of Nannochloropsis sp. experienced a lag phase, which is the adaptation phase of microalgae in new environmental conditions that differ from the previous inoculum culture conditions. The differences between the inoculum culture and the culture conditions during the treatment include the difference in the spectrum of white and blue light, the surface area exposed to the light, and the difference between the stirring aeration and an airlift system. This adaptation makes the culture of Nannochloropsis sp. a process that takes time to reach the exponential phase. Therefore, the growth process of Nannochloropsis sp. can still be improved by first adapting the inoculum to the optimum conditions before inoculation on a large-scale photobioreactor. If the culture of Nannochloropsis sp. has been adapted to the optimum conditions, the lag phase can be shortened or even eliminated to increase growth efficiency.

The use of lighting systems (flashing, LED lights) can increase the yield of microalgae by eight times because the light that is used can be adjusted in wavelength in order to increase the effectiveness of light absorption (Vidt 2016). The results of Sato et al. (2010) showed that the cultivation of microalgae Chaetoceros gracilis using a flashing light produced a dry weight of $0.84 \mathrm{~g} / \mathrm{L} /$ day or $5 \%$ more, compared to continuous light. The condition of microalgae culture under continuous light is known to cause photoinhibition. Photoinhibition is a photosystem II damage that is induced by light. The damage to the photosystem triggers the inactivation of other systems, including the formation of oxygen systems, electron carriers, and proteins associated with light cycle reactions (Rubio et al. 2003). The result of this photo exhibit is the reduction of the effectiveness of light absorption and an impact on biomass productivity. The dark period, as part of the flashing light treatment, provides a time without light in order to repair the photosystem damage. Therefore, alternating dark and bright periods in flashing light treatment can increase the photosynthetic efficiency.

Based on our observations, the death rate of Nannochloropsis sp. cells in each flashing light treatment tends to increase with the age of culture. The highest mortality rate was found in cultures with P3 flashing light treatment $(0.25: 0.75 \mathrm{~h})$. At the end of the culture process, the number of cell deaths in the treatment reached 0.36 x $10^{6}$ cells $/ \mathrm{mL}$. The lowest mortality rate was found in the treatment P1 $(0.75: 0.25 \mathrm{~h})$ with the number of cell deaths being $0.01 \times 10^{6}$ cells $/ \mathrm{mL}$ (Fig. 6a). The highest mortality rate, which was observed in the P3 flashing light treatment $(0.25: 0.75 \mathrm{~h})$, is considered to be caused by a lack of irradiation time (light period). The absorption of light, which is needed for the photosynthesis, was reduced, while many cell deaths in the control treatment were likely due to contaminants that interfered with the growth process. The results show that the number of contaminants during the culture period in each treatment has increased. At the end of the culture period, the highest number of contaminants was found in the control culture $\left(0.1 \times 10^{6}\right.$ cells $\left./ \mathrm{mL}\right)$, followed by the P3 treatment $(0.25: 0.75 \mathrm{~h})$ with a total number of $0.05 \times 10^{6}$ cells/ $\mathrm{mL}$ (Fig. 6b).

The number of contaminants increases with the number of dead cells. This is caused by the fact that dead cells constitute food for contaminants. The main type of contaminants that was observed during the research on Nannochloropsis sp., was ciliate. A ciliate is a group of protozoa that live and move actively in water with the help of a locomotor called cilia. When the number of contaminants belonging to this type of ciliate increases, the color of the culture turns yellowish.

In the P3 treatment $(0.25: 0.75 \mathrm{~h})$, the $\mathrm{pH}$ value was found to be the lowest compared to the other treatments. There was a significant decrease in $\mathrm{pH}$ at the end of the culture period, which lasted for 10 days. The death of a large number of cells that occurred in this period resulted in a decrease in $\mathrm{pH}$. This was caused by the accumulation of organic matter originating from the remains of dead microalgae.

Based on the results of the measurement of the degree of acidity that was performed during the culture period, we conclude that when the lights are on, all treatments are relatively stable, with the acidity level ranging between 6.1 and 7.9. At the beginning of the culture period, the highest degree of acidity (7.6) was obtained from the control treatment. On the other hand, the lowest acidity degree (6.9) was obtained from the treatment P1 $(0.75: 0.25 \mathrm{~h})$. During the culture period, the lowest acidity degree (6.1) was obtained from the P3 treatment $(0.25: 0.75 \mathrm{~h})$ on the $10^{\text {th }}$ day. The decrease in $\mathrm{pH}$ is considered to be caused by the increased number of contaminants that is observed during that period. Overall, the $\mathrm{pH}$ value obtained during the light period (when the lamp was on) (Fig. 6c) was less than the $\mathrm{pH}$ value measured during the dark period (when the lamp was off) (Fig. 6d). An increase 

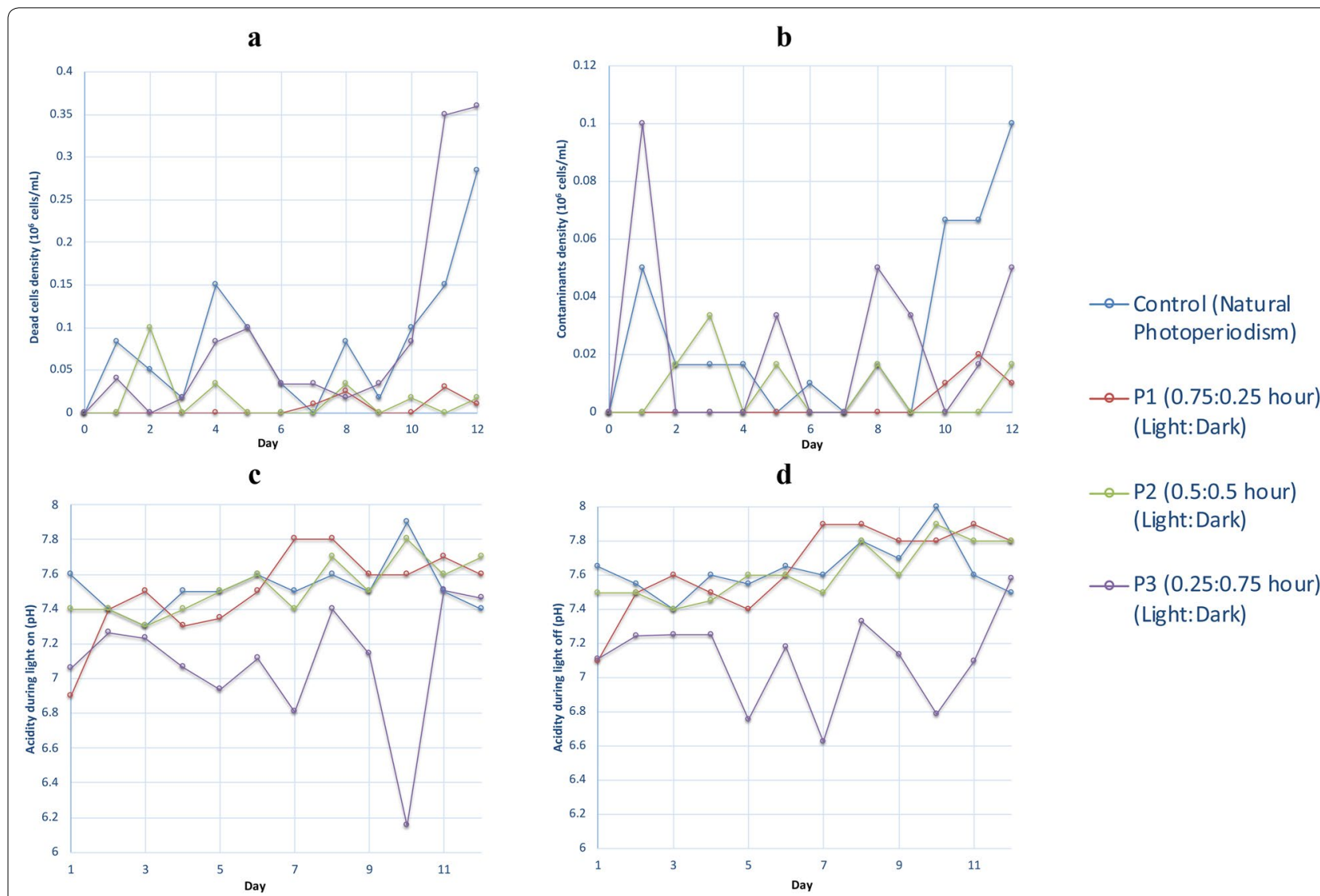

(Light:Dark)

$\multimap$ - P3 (0.25:0.75 hour) (Light:Dark)

Fig. 6 Curve of (a) dead cells of Nannochloropsis sp., (B) contaminants, (c) pH graph when the light is on and (d) pH graph when the light is off in the four low-frequency flashing light treatments

in $\mathrm{pH}$ during the dark period is considered to be caused by the dark period that triggers a dark reaction in the photosynthesis process of microalgae, thereby triggering $\mathrm{CO}_{2}$ fixation.

During the culture period, ammonium, nitrate, and orthophosphate concentrations in the culture of Nannochloropsis sp. tend to fluctuate (Fig. 6a, 6c, 6d). Nitrate concentration is decreasing due to absorption by microalgae. In contrast, nitrate concentration is increasing caused by assimilation in the nitrogen cycle by bacteria (Fig. 6b). The highest levels of nitrite, equal to $0.9 \mathrm{ppm}$, were obtained in the P3 treatment $(0.25: 0.75 \mathrm{~h})$, a condition which is toxic for the microalgae culture of Nannochloropsis sp. thus causing a high number of cell deaths. Nitrite concentrations increased within the culture period caused by a preference for nitrogen uptake, more probably of ammonium and nitrates. Orthophosphate, nitrates, and ammonium concentrations tend to be constant due to the assimilation of dead cells by bacteria and their absorption by microalgae as a macronutrient requirement (Rocha et al. 2003; Lu et al. 2013).
Nitrite $\left(\mathrm{NO}_{2}^{-}\right)$is an intermediate compound of the nitrification process that converts ammonium to nitrate. This compound is toxic in water. Therefore, when at the end of the culture period the nitrite concentration increases, the cell death rate also increases. Nitrite concentration is greatly influenced by the process of nitrification, a process during which nitrites are converted into nitrates with the help of the bacterium Nitrobacter. When the nitrite has been nitrified to nitrate, the nitrite concentration decreases and it is no longer toxic in water (Bothe et al. 2007).

Nitrate $\left(\mathrm{NO}_{3}^{-}\right)$is the result of the nitrification process of ammonia and nitrite. Nitrate compounds can be converted, through denitrification, to $\mathrm{N}_{2} \mathrm{O}$ and $\mathrm{N}_{2}$ gas by introducing anaerobic bacteria under natural conditions. In the case when there is absorption of nitrates by microalgae, the $\mathrm{pH}$ of the culture increases (Rubio et al. 2003; Hulatt and Thomas 2011). Nitrates can be directly absorbed by microalgae since the former constitute a source of nutrition covering microalgae nitrogen needs.

Phosphorus is an essential element for microalgae growth and constitutes a limiting factor regarding the 
level of their productivity in water (Solovchenko et al. 2016). Phosphorus is not found as a free element in water or the atmosphere. It can be found in water but always in the form of phosphate $\left(\mathrm{PO}_{4}{ }^{3-}\right)$. Fluctuations in the orthophosphate concentration indicate the absorption of phosphate by microalgae from the Modified II Walne medium and the recycling of Nannochloropsis sp. dead cells.

The concentration of dissolved $\mathrm{CO}_{2}$, measured once every 2 days in all treatments, decreased. At the beginning of the culture, $\mathrm{CO}_{2}$ concentrations ranging from $24.66 \mathrm{mg} / \mathrm{L}-32.5 \mathrm{mg} / \mathrm{L}$ were found in the $\mathrm{P} 1$
$(0.75: 0.25 \mathrm{~h})$ and P3 (0.25:0.75 h) treatments. Moreover, at the end of the culture period, $\mathrm{CO}_{2}$ concentrations ranging from $12.5 \mathrm{mg} / \mathrm{L}-28.54 \mathrm{mg} / \mathrm{L}$, were found in the P1 (0.75:0.25 h) and control treatments (Fig. 7e).

The content of dissolved $\mathrm{CO}_{2}$ is strongly related to $\mathrm{pH}$ levels. The decrease of the dissolved $\mathrm{CO}_{2}$ content directly affects the increase in $\mathrm{pH}$, since $\mathrm{CO}_{2}$ compounds are acidic. The decrease in the $\mathrm{CO}_{2}$ concentration, which takes place from the beginning to the end of the culture period, is a result of the consumption of $\mathrm{CO}_{2}$ by microalgae culture Nannochloropsis sp. The
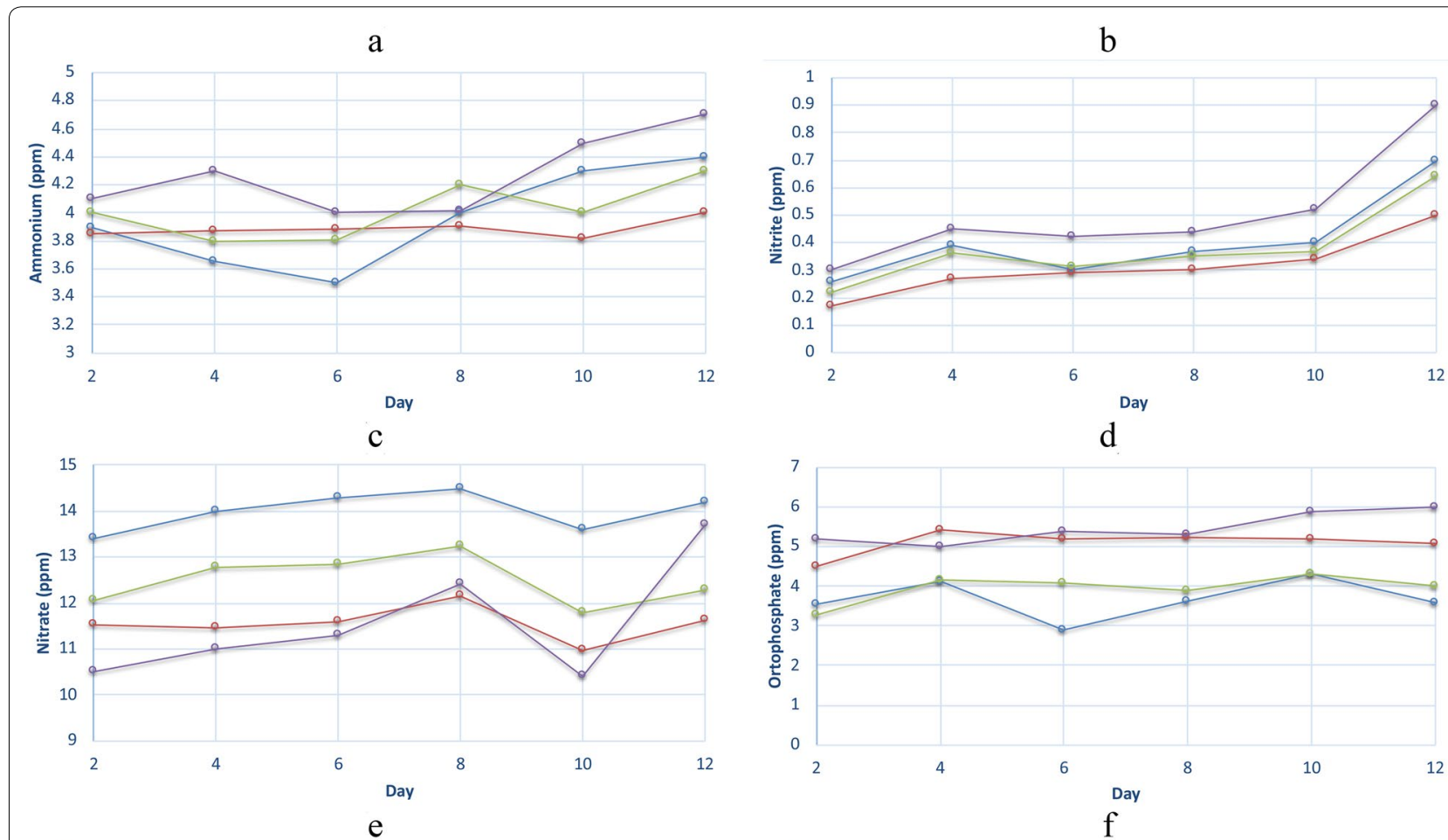

d
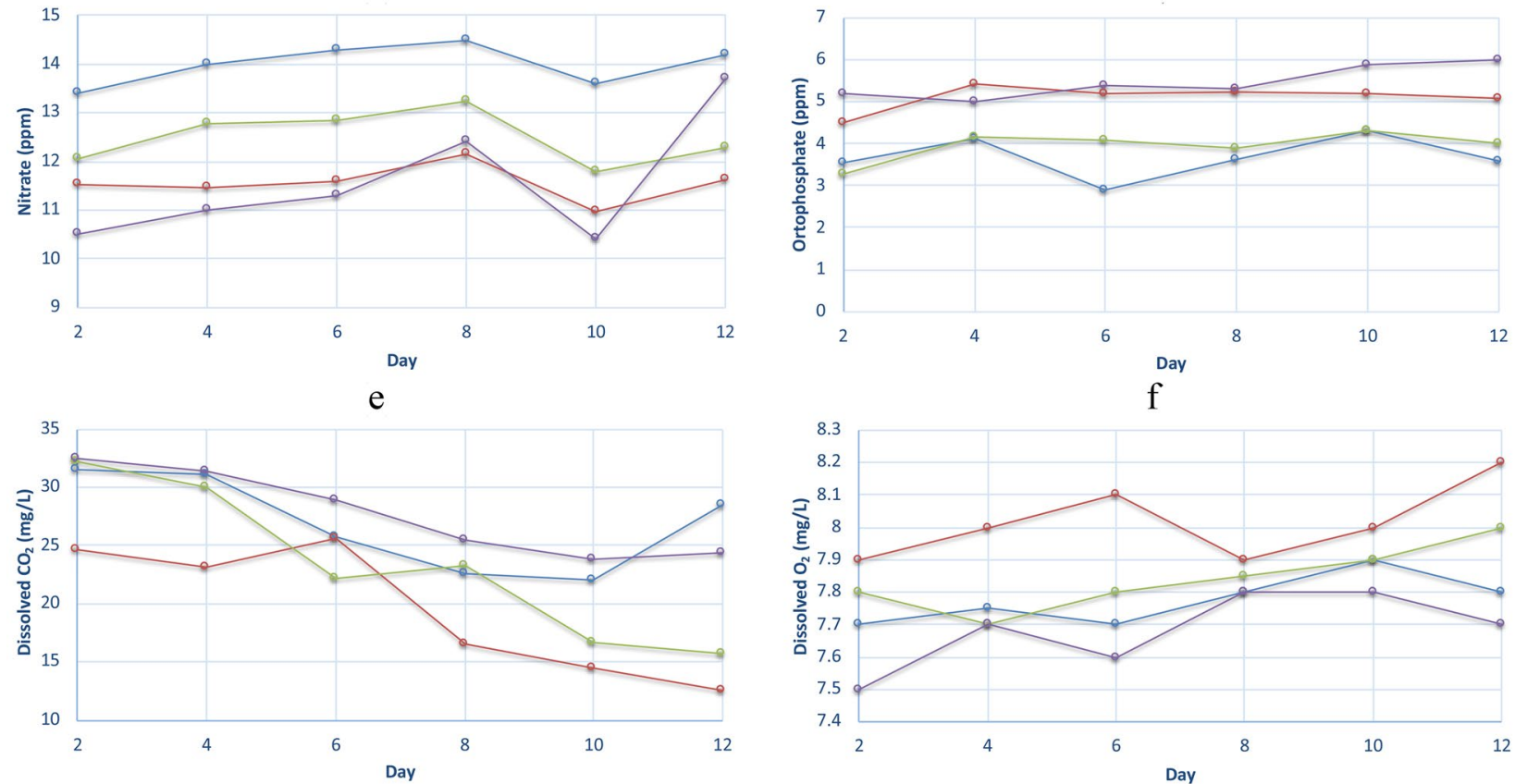

$\multimap$ C Control (Natural Photoperiodism) —P1 (0.75:0.25 hour) (Light:Dark)

—P2 (0.5:0.5 hour) (Light:Dark) — - P3 (0.25:0.75 hour) (Light:Dark)

Fig. 7 Curve concentration of (a) ammonium, (B) nitrite, (c) nitrate, (d) orthophosphate, (e) dissolved $\mathrm{CO}_{2}$, and (f) dissolved $\mathrm{O}_{2}$ in the four low-frequency flashing light treatments 
number of microalgae is increasing while the $\mathrm{CO}_{2}$ supply due to aeration is relatively fixed.

The decrease in $\mathrm{CO}_{2}$ concentration in all treatments reached an average on day four of the Nannochloropsis sp. cell growth process. On day four, the growth reached an exponential phase resulting in an increased need for $\mathrm{CO}_{2}$ that is used as raw material for photosynthesis. Under these conditions, the availability of dissolved $\mathrm{CO}_{2}$ levels is limiting the growth of the microalgae culture of Nannochloropsis sp. Therefore, it is necessary to add $\mathrm{CO}_{2}$ in the exponential phase, when the concentration of $\mathrm{CO}_{2}$ begins to decrease, followed by an increase in $\mathrm{pH}$.

The concentration of dissolved $\mathrm{O}_{2}$ was measured in order to determine the rate of photosynthesis by microalgae culture since $\mathrm{O}_{2}$ is one of the results of photosynthesis during light reactions. Based on the measurement results, the concentration of dissolved $\mathrm{O}_{2}$ in all treatments increased. At the beginning of the culture, $\mathrm{O}_{2}$ concentrations ranging from $7.5 \mathrm{mg} / \mathrm{L}-7.9 \mathrm{mg} / \mathrm{L}$ were found in the P3 $(0.25: 0.75 \mathrm{~h})$ and P1 $(0.75: 0.25 \mathrm{~h})$ treatments. At the end of the culture period, $\mathrm{O}_{2}$ concentrations ranging from $7.7 \mathrm{mg} / \mathrm{L}-8.2 \mathrm{mg} / \mathrm{L}$ were found in the P3 (0.25:0.75 h) and P1 (0.75:0.25 h) treatments (Fig. 7f). According to Park \& Lee (2001), the rate of specific oxygen production in Chlorella kessleri microalgae culture is higher under flashing light conditions than under continuous light conditions. The highest $\mathrm{O}_{2}$ levels were produced by P1 treatment $(0.75: 0.25 \mathrm{~h})$, which was characterized by the highest cell density.

Based on the results of Pearson's linear correlation analysis (Additional file 1: Table S2), we drew the conclusion that the parameters of the concentration of ammonium, nitrate, nitrite, orthophosphate, dissolved oxygen, and $\mathrm{pH}$ in the culture are positively correlated to the growth of Nannochloropsis sp. in almost all treatments except for P3 (0.25:0.75 h). On the other hand, the concentration of dissolved $\mathrm{CO}_{2}$ shows a negative correlation to the growth of Nannochloropsis sp. in almost all treatments. Based on these correlations, it can be extracted that the higher the concentration of dissolved $\mathrm{CO}_{2}$ in the culture, the lower the growth of Nannochloropsis sp.

Harvesting of microalgae Nannochloropsis sp. was conducted on day 12 using centrifugation in order to obtain wet biomass in the form of pasta. After drying in the oven, the biomass is crushed to form a flour. The use of this scouring process is to simplify the extraction process, which will be carried out at a later stage. Based on the results of biomass weight yields, it is concluded that the highest biomass weight was achieved in P1 treatment $(0.75: 0.25 \mathrm{~h})$. The treatment resulted in a wet weight of $7.11 \mathrm{~g}$ from a culture volume of $35 \mathrm{~L}$ with a net volume of $+30 \mathrm{~L}$, because the volume of the culture was reduced due to the daily sampling for a period of 12 days. The second highest biomass weight was observed in the P2 treatment $(0.5: 0.5 \mathrm{~h})$ with a wet weight of $6.65 \mathrm{~g}$. The lowest wet weight was obtained in the control treatment $(3.86 \mathrm{~g})$, whereas in the P3 treatment $(0.25: 0.75 \mathrm{~h})$ the weight could not be obtained because the cell density at the end of the culture period was almost zero (Fig. 8a). The consideration that the low level of nitrate, orthophosphate, and high radiation can enhance the amount of saturated and monosaturated fatty acids in microalgal cultivation is also supported by Allen et al. (2018).

Regarding the biomass productivity of Nannochloropsis sp., we obtained the optimum results in P1 treatment (0.75:0.25 h). Under P1 conditions, we can produce biomass of $0.029625 \mathrm{~g} / \mathrm{L} /$ day wet weight and $0.005014 \mathrm{~g} / \mathrm{L} /$ day dry weight. However, the wet weight can be calculated from the estimation of the single cell volume and the specific density from the microalgae culture of Nannochloropsis $\mathrm{sp}$. The cell volume can be assumed to be the volume of the sphere due to the globular shape of Nannochloropsis sp cells. Cell properties of Nannochloropsis sp. include floating in the water medium that leads us to the

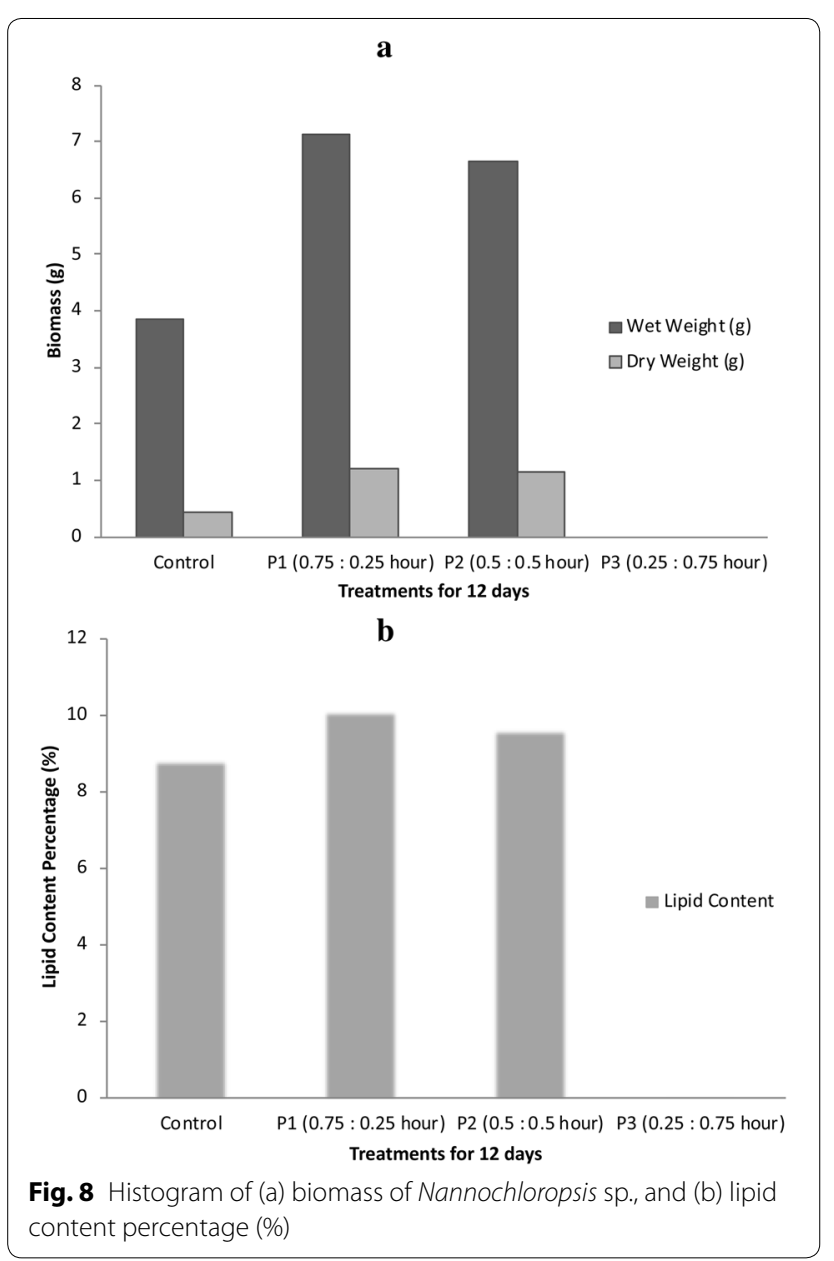


assumption that the cell's specific gravity is close to the water's specific density, which is $\sim 0.9 \mathrm{~g} / \mathrm{mL}$.

Ball volume can be calculated by the formula:

$$
\begin{aligned}
\text { Volume } 1 \text { natural cell } & =\frac{\pi}{6}(d)^{3} \\
& =0.524\left(2 \times 10^{-4} \mathrm{~cm}\right)^{3} \\
& =1.048 \times 10^{-12} \mathrm{~mL},
\end{aligned}
$$

Volume 1 in vitro cell $=\frac{\pi}{6}(d)^{3}$

$$
\begin{aligned}
& =0.524\left(5 \times 10^{-4} \mathrm{~cm}\right)^{3} \\
& =2.619 \times 10^{-12} \mathrm{~mL}
\end{aligned}
$$

Weight 1 natural cell $=\rho_{\text {sel }} \times$ volume cell

$$
\begin{aligned}
& =0.9 \times 1.048 \times 10^{-12} \\
& =0.9432 \times 10^{-12} \mathrm{~g},
\end{aligned}
$$

Weight 1 in vitro cell $=\rho_{\text {sel }} \times$ volume sel

$$
\begin{aligned}
& =0.9 \times 2.619 \times 10^{-12} \\
& =2.3571 \times 10^{-12} \mathrm{~g},
\end{aligned}
$$

where $\rho_{\text {sel }}$ denotes cell-specific density $(\mathrm{g} / \mathrm{mL})$. Meanwhile, $d$ indicates cell diameter which measured by hemocytometer. The hemocytometer size was about $5 \times 10^{-4} \mathrm{~cm}$.

Once the weight of one microalgae Nannochloropsis sp. cell is calculated, the total culture weight can be calculated. Therefore, an estimation of the total wet weight can be extracted as follows:

$$
\begin{aligned}
& \sum \text { cell weight (natural) } \\
& =0.9432 \times 10^{-12} \times 10 \times 10^{6} \\
& =0.9432 \times 10^{-5} \mathrm{~g} \mathrm{~mL}^{-1} \\
& \sum \text { cell weight (in vitro) } \\
& =2.3571 \times 10^{-12} \times 17 \times 10^{6} \\
& =40.071 \times 10^{-5} \mathrm{~g} \mathrm{~mL}^{-1}, \\
& \sum \text { cell weight }=\sum \text { cell weight (natural) } \\
& \quad+\sum \text { cell weight (in vitro) }
\end{aligned}
$$

so that the total wet weight can be calculated by: $\sum$ total wet weight (in vitro)

$$
\begin{aligned}
= & \sum \text { cell weight } \times 1000 \mathrm{~L}^{-1} \\
& \times 30 \mathrm{~L}=40.071 \times 10^{-2} \mathrm{~g} \mathrm{~L}^{-1} \\
& \times 30 \mathrm{~L}=12.021 \mathrm{~g} .
\end{aligned}
$$

Therefore, the estimated total wet weight from the treatment of P1 $(0.75: 0.25 \mathrm{~h})$ in $30 \mathrm{~L}$ is $12.021 \mathrm{~g}$. On the other hand, the harvesting results of the $12,000 \mathrm{~g}$ centrifugation method that was conducted for 10 min produced only a wet weight of $7.11 \mathrm{~g}$. Based on these results, we can conclude that $4911 \mathrm{~g}$ or $40 \%$ of the wet biomass is lost in the harvesting process. Therefore, the harvesting process affects biomass and lipid productivity significantly.

The results of lipid extraction under the flashing light conditions of the P1 treatment $(0.75: 0.25 \mathrm{~h})$ produced the highest lipid content which reached $10.1 \%$ of the dry weight, followed by the biomass that was derived from the P2 treatment $(0.5: 0.5 \mathrm{~h})$ with a lipid content reaching $9.6 \%$. On the other hand, the lowest lipid content obtained from biomass $(8.8 \%)$ was derived from the control treatment. In the P3 treatment $(0.25: 0.75 \mathrm{~h})$, lipid extraction was not possible because cell deaths occurred during harvesting, until the cell density was almost zero (Fig. 8b).

According to Rodolfi et al. (2009), the biomass productivity of Nannochloropsis sp. under phototropic conditions of $0.17 \mathrm{~g} / \mathrm{L} /$ day produces lipid content of $21.6 \%$ dry weight, which is around $37.6 \mathrm{mg} / \mathrm{L} /$ day. Meanwhile, Chisti (2007) reported that the percentage of lipid levels of Nannochloropsis ${ }^{\mathrm{s} 6 \mathrm{p}}$. ranged from $31-68 \%$ dry weight. Based on the results in this study, the flashing light treatment produces lipid levels ranging from 8.8 to $0.1 \%$ dry weight, which is around $0.5064 \mathrm{mg} / \mathrm{L} /$ day. The difference presented in the lipid content of Nannochloropsis sp. is considered to be a result of the differences in the species of Nannochloropsis used in previous studies. Another possible cause is that the Bligh and Dyer extraction method that was used is not the optimal for this type of microalgae.

Based on Chen and Lee (2012) and Chisti (2007), the cell density of Nannochloropsis sp. in nature is around $10^{7}$ cells $/ \mathrm{mL}$ with $2 \mu \mathrm{m}$ diameters, $68 \%$ lipid content and $20 \%$ dried weight. In contrast, the highest cell density of the optimum experiment in this study is around $17 \times 10^{6}$ cells $/ \mathrm{mL}, 5 \mu \mathrm{m}$ in diameters, $10.1 \%$, and $20 \%$ dried weight. We calculate the lipid productivity as follows:

$$
\begin{aligned}
& \text { Lipid productivity } \\
& =\frac{\sum \text { cell weight } \times \% \text { dried weight } \times \% \text { lipid }}{\text { culture period }}
\end{aligned}
$$

In natural condition, we obtained lipid productivity as shown below 
Lipid productivity (nature)

$$
\begin{aligned}
& =\frac{0.9432 \times 10^{-5} \times 0.2 \times 0.68}{8} \\
& =0.16025 \times 10^{-6} \mathrm{~g} \mathrm{~mL}^{-1} \text { day }^{-1}
\end{aligned}
$$

On the other hand, the optimum P1 treatment $(0.75: 0.25 \mathrm{~h})$ (in vitro) produce lipid as follows:

$$
\begin{aligned}
& \text { Lipid productivity (in vitro) } \\
& =\frac{40.071 \times 10^{-5} \times 0.2 \times 0.101}{8} \\
& =10.01775 \times 10^{-6} \mathrm{~g} \mathrm{~mL}^{-1} \mathrm{~d}^{-1}
\end{aligned}
$$

Hence, the calculation showed that lipid productivity in Nannochloropsis sp. with low-frequency flashing light with blue LED [P1 treatment $(0.75: 0.25 \mathrm{~h})]$ produces 61 times higher than lipid productivity of Nannochloropsis sp. in natural light.

\section{Conclusions}

The main object of this study was the enhanced factor of biomass productivity of microalgae Nannochloropsis sp. in an airlift photobioreactor using flashing light with blue LED. The optimum flashing light conditions for Nannochloropsis sp. on the batch culture airlift photobioreactor system is a flashing light ratio of $(0.75: 0.25 \mathrm{~h}$, light:dark) which produces a cell density of $17 \times 10^{6}$ cells $/ \mathrm{mL}$, wet biomass of $7.11 \mathrm{~g}$, biomass productivity of $0.005014 \mathrm{~g} / \mathrm{L} /$ day dry weight, and lipid content of $10.1 \%$ or $0.5064 \mathrm{mg} / \mathrm{L} /$ day.

The use of airlift photobioreactors with blue LED lights increases efficiently the cell growth by $70 \%$ compared to the growth of Nannochloropsis sp. in nature and produces 61 times higher lipid content compared to Nannochloropsis sp. that is exposed to natural light. The subsequent step was carried out by maintaining a constant level of dissolved $\mathrm{CO}_{2}$ by adding aeration of $\mathrm{CO}_{2}$ when $\mathrm{CO}_{2}$ levels dropped. Moreover, optimal conditions for the cultivation of Nannochloropsis sp. were obtained in the continuous culture system.

\section{Supplementary information}

Supplementary information accompanies this paper at https://doi. org/10.1186/s40643-020-00331-9.

Additional file 1. Additional tables

\section{Acknowledgements}

We thank the Editor and anonymous reviewer for constructive and helpful comments to improve the manuscript. Also, we sincerely grateful for Plants Science and Biotechnology Laboratory and Ecology Laboratory, School of Life Science and Technology, Bandung Institute of Technology, Bandung, Indonesia, for full assistance in conducting the experiments.

\section{Authors' contributions}

NY carried out the overall experiments, analyzed the data, and drafted the manuscript. RM and GS supervised the experiment and reviewed the manuscript before submission.

\section{Funding}

Not applicable

\section{Availability of data and material}

Data will be made available upon request.

Ethics approval and consent to participate

Not applicable

Consent for publication

Not applicable

Competing interests

The authors declare that there is no conflicts of interest.

\section{Author details}

${ }^{1}$ Plant Structure and Development Laboratory, Faculty of Biology, Gadjah Mada University, Yogyakarta, Indonesia. ${ }^{2}$ Agrotechnology and Bioproduct Technology Research Group, School of Life Science and Technology, Bandung Institute of Technology, Bandung, Indonesia. ${ }^{3}$ Microbial Biotechnology Research Group, School of Life Science and Technology, Bandung Institute of Technology, Bandung, Indonesia.

Received: 2 January 2020 Accepted: 7 July 2020

Published online: 20 July 2020

\section{References}

Allen J, Unlu S, Demirel Y, Black P, Riekhof W (2018) Integration of biology, ecology and engineering for sustainable algal-based biofuel and bioproduct biorefinery. Bioresources and Bioprocessing. https://doi.org/10.1186/ s40643-018-0233-5

Anderson RA (2005) Algal culturing techniques. J Chem Inf Model. https://doi. org/10.1017/CBO9781107415324.004

Aziz HA, Dianursanti D (2018) Production of microalgae Nannochloropsis oculata biomass in a bubble column photobioreactor with integrated lighting through adjustment of light intensity and air flow rate. AIP Conf Proc. https://doi.org/10.1063/1.5064326

Bligh EG, Dyer WJ (1959) A rapid method of total lipid extraction and purification. Can J Biochem Physiol. https://doi.org/10.1139/o59-099

Bothe H, Ferguson S, Newton WE (2007) Biology of the Nitrogen Cycle. Biol Nitrogen Cycle. https://doi.org/10.1016/B978-0-444-52857-5.X5000-0

Chen Y, Lee M (2012) Double-power double-heterostructure light-emitting diodes in microalgae, spirulina platensis and nannochloropsis oculata, cultures. J Mar Sci Technol 20(2):233-236

Chisti Y (2007) Biodiesel from microalgae. 25:294-306. https://doi. org/10.1016/j.biotechadv.2007.02.001

Chisti Y (2008) Biodiesel from microalgae beats bioethanol. Trends Biotechnol. https://doi.org/10.1016/j.tibtech.2007.12.002

Chiu S, Kao C, Tsai M, Ong S, Chen C, Lin C (2009) Bioresource Technology Lipid accumulation and CO 2 utilization of Nannochloropsis oculata in response to CO 2 aeration. Biores Technol 100(2):833-838. https://doi. org/10.1016/j.biortech.2008.06.061

Das P, Lei W, Sarah S, Philip J (2011) Bioresource Technology Enhanced algae growth in both phototrophic and mixotrophic culture under blue light. Biores Technol 102(4):3883-3887. https://doi.org/10.1016/j.biort ech.2010.11.102

Guillard RRL, Sieracki MS (2005) Counting cells in cultures with the light microscope. Algal Culturing Tech. https://doi.org/10.1016/b978-01208 8426-1/50017-2

Huang Q, Jiang F, Wang L, Yang C (2017) Design of Photobioreactors for Mass Cultivation of Photosynthetic Organisms. Engineering 3(3):318-329. https ://doi.org/10.1016/J.ENG.2017.03.020 
Hulatt CJ, Thomas DN (2011) Productivity, carbon dioxide uptake and net energy return of microalgal bubble column photobioreactors. Bioresour Technol. https://doi.org/10.1016/j.biortech.2011.02.025

Krzemińska I, Pawlik-Skowrońska B, Trzcińska M, Tys J (2014) Influence of photoperiods on the growth rate and biomass productivity of green microalgae. Bioprocess Biosyst Eng. https://doi.org/10.1007/s00449-013-1044-x

Kulkarni MG, Dalai AK (2006) Waste cooking oil - An economical source for biodiesel: a review. Ind Eng Chem Res. https://doi.org/10.1021/ie0510526

Le Chevanton M, Garnier M, Lukomska E, Schreiber N, Cadoret JP, Saint-Jean B, Bougaran G (2016) Effects of nitrogen limitation on Dunaliella sp.-Alteromonas sp. interactions: from mutualistic to competitive relationships. Frontiers in Marine Science. https://doi.org/10.3389/fmars.2016.00123

Lee JY, Yoo C, Jun SY, Ahn CY, Oh HM (2010) Comparison of several methods for effective lipid extraction from microalgae. Biores Technol. https://doi. org/10.1016/j.biortech.2009.03.058

Lu, X., Zhang, Q., Lu, M., Dou, X., Huang, C., Jia, J., \& Ji, J. (2013). Effects of nitrogen sources on growth density, lipid yield and eicosapentaenoic acid of Nannochloropsis oculata. Shengwu Gongcheng Xuebao/Chinese Journal of Biotechnology

Marrez DA, Cieślak A, Gawad R, Ebeid HM, Chrenková M, Gao M, Yanza YR, ElSherbiny M, Szumacher-Strabel M (2017) Effect of freshwater microalgae Nannochloropsis limnetica on the rumen fermentation in vitro. J Anim Feed Sci 26(4):359-364. https://doi.org/10.22358/jafs/81275/2017

Oo N, Su C, Kyaw T (2017) Extraction And Determination Of Chlorophyll Content From Microalgae. International Journal of Advanced Research and Publications 1(5):298

Park KH, Lee CG (2001) Effectiveness of flashing light for increasing photosynthetic efficiency of microalgal cultures over a critical cell density. Biotechnol Bioprocess Eng. https://doi.org/10.1007/BF02932549

Rocha JMS, Garcia JEC, Henriques MHF (2003) Growth aspects of the marine microalga Nannochloropsis gaditana. Biomol Eng. https://doi. org/10.1016/S1389-0344(03)00061-3

Rodolfi L, Zittelli GC, Bassi N, Padovani G, Biondi N, Bonini G, Tredici MR (2009) Microalgae for oil: strain selection, induction of lipid synthesis and outdoor mass cultivation in a low-cost photobioreactor. Biotechnol Bioeng. https://doi.org/10.1002/bit.22033
Rubio Camacho F, García Camacho F, Fernández Sevilla JM, Chisti Y, Molina Grima E (2003) A mechanistic model of photosynthesis in microalgae. Biotechnol Bioeng. https://doi.org/10.1002/bit.10492

Sato T, Yamada D, Hirabayashi S (2010) Development of virtual photobioreactor for microalgae culture considering turbulent flow and flashing light effect. Energy Convers Manage. https://doi.org/10.1016/j.encon man.2009.12.030

Silva HJ, Pirt SJ (1984) Carbon dioxide inhibition of photosynthetic growth of chlorella. J Gen Microbiol. https://doi.org/10.1099/00221287-130-11-2833

Solovchenko A, Verschoor AM, Jablonowski ND, Nedbal L (2016) Phosphorus from wastewater to crops: An alternative path involving microalgae. Biotechnol Adv. https://doi.org/10.1016/j.biotechadv.2016.01.002

Sudibyo H, Pradana YS, Samudra TT, Budiman A, Suyono EA (2017) Study of Cultivation under Different Colors of Light and Growth Kinetic Study of cultivation under different colors of light and growth kinetic study of Chlorella zofingiensis Dönz for biofuel production. Energy Procedia 105(June):270-276. https://doi.org/10.1016/j.egypro.2017.03.313

Taisir M, Teo CL, Idris A, Yusuf AM (2016) Cultivation of Nannochloropsis sp. using narrow beam angle light emitting diode in an internally illuminated photobioreactor. Bioresour Bioprocess. https://doi.org/10.1186/ s40643-016-0113-9

Vidt DJ (2016) Subterranean photobioreactors for commercial-industrial scale algal culture. Doctoral Dissertations. 2493. https://scholarsmine.mst.edu/ doctoral_dissertations/2493

Wagner L (2007) Biodiesel from algae oil. Biol Sci. https://doi.org/10.1007/9781-84996-050-2

Xu F, Hu HH, Cong W, Cai ZL, Ouyang F (2004) Effects of air flow rate and $\mathrm{CO}_{2}$ concentration on the growth of Nannochloropsis sp. and EPA accumulation in an airlift photobioreactor. Chinese Journal of Process Engineering. $4(5): 457-461$

\section{Publisher's Note}

Springer Nature remains neutral with regard to jurisdictional claims in published maps and institutional affiliations.

\section{Submit your manuscript to a SpringerOpen ${ }^{\circ}$ journal and benefit from:}

- Convenient online submission

- Rigorous peer review

- Open access: articles freely available online

- High visibility within the field

- Retaining the copyright to your article

Submit your next manuscript at $\boldsymbol{\nabla}$ springeropen.com 